\title{
Jedyna wspólna akcja. Krótkie życie Zbigniewa Kuźmińskiego
}

Tytuł artykułu nie jest oczywiście odniesieniem do kontaktów filmowych Polski i Słowacji. Na przestrzeni lat powstało kilka filmów zrealizowanych we współpracy ze słowackimi filmowcami ${ }^{1}$. Krótkie życie (1976, słowacki tytuł: Krátky život) Zbigniewa Kuźmińskiego było jednak pierwszym obrazem, który powstał przy udziale filmowców z bratysławskiej wytwórni. Choćby $\mathrm{z}$ tego względu warto poświęcić temu filmowi uwagę. Ale nie tylko. Jest to bowiem film zapomniany, nieemitowany od wielu lat, który nie odniósł sukcesu ani wśród publiczności kinowej, ani na festiwalach². Dość wspomnieć, że w celu obejrzenia go konieczna jest projekcja z taśmy w Filmotece Narodowej, gdyż nie jest on dostępny na jakimkolwiek nośniku. Artykuł ten będzie poświęcony nie tylko powstawaniu filmu w koprodukcji z Wytwórnią Filmową Koliba, lecz także odtwarzaniu jego scenariusza, różnic pomiędzy scenariuszem a filmem oraz ocenie filmu przez komisję kolaudacyjną i recenzentów. By jednak rozpocząć, musimy cofnąć się do pierwszych lat po II wojnie światowej. Wtedy właśnie miały miejsce wydarzenia, które stanowiły kanwę najpierw opowiadania Stanisława Wałacha, a później scenariusza Aleksandra Rowińskiego, który dzięki Zbigniewowi Kuźmińskiemu przybrał w 1976 roku ekranowy kształt.

* Uniwersytet Łódzki.

${ }^{1}$ Wytwórnia Filmowa Koliba, przy współpracy której zrealizowany został film Krótkie życie, pojawia się również w czołówkach takich tytułów, jak: Sto koni do stu brzegów (1978, reż. Zbigniew Kuźmiński) czy Pan Kleks w kosmosie (1988, reż. Krzysztof Gradowski). Sam Kuźmiński przy Sto koni do stu brzegów korzystał też z usług produkcyjnych Studia Filmowego Barrandov.

${ }^{2}$ Według Aleksandra Rowińskiego film był bardziej popularny w Czechosłowacji niż w Polsce. Potwierdzeniem tych słów może być nagroda, jaką otrzymał w 1977 roku na 15. Festiwalu Czechosłowackiego Filmu w Bratysławie. Jednocześnie było to jedyne wyróżnienie, jakie w ogóle zdobył film Kuźmińskiego, za: Renáta Šmatláková, Katalóg slovenských celovečerných filmov 1921-1999, Slovenský filmový ústav, Bratislava 1999, s. 106. 


\section{Pierwowzór literacki i scenariusz filmu}

W 1969 roku, nakładem Wydawnictwa Literackiego, ukazało się pierwsze wydanie książki Stanisława Wałacha Był w Polsce czas... Publikacja autorstwa wysokiego funkcjonariusza krakowskiego Urzędu Bezpieczeństwa opisywała pierwsze lata po II wojnie światowej oraz wprowadzanie i utrwalanie władzy komunistycznej na terenie Polski. Wśród kilku nowel pomieszczonych w tym tomie znajduje się również opowiadanie Żandarmeria, które stało się podstawą filmu Krótkie życie. Wałach opisał w nim likwidację tytułowej "Żandarmerii" - zbrojnego oddziału Polskiej Podziemnej Armii Niepodległościowej, dowodzonego przez Stanisława Pióro „Emira”. Organizacja ta powstała w 1946 roku, a jej celem była „walka o Niepodległą Polskę" ${ }^{3}$ oraz „przygotowanie kadr, które odegrałyby znaczącą rolę podczas przejmowania władzy w wyniku ewentualnego konfliktu między państwami zachodnimi a ZSRR"4. Od 1948 roku była inwigilowana przez kilku współpracowników i agentów Urzędu Bezpieczeństwa. Pod wpływem kolejnych aresztowań „Emir" podjął decyzję o ucieczce z Polski i przedarciu się do Austrii. Jednak łącznik, który miał przeprowadzić oddział przez Czechosłowację, okazał się podstawionym oficerem czechosłowackiego Urzędu Bezpieczeństwa. Dnia 12 sierpnia 1949 roku na odcinku drogi z Forbasów do Nižnych Ružbachów autobus, w którym znajdowali się członkowie "Żandarmerii", został otoczony przez liczne oddziały polskiego i czechosłowackiego UB. „Emir” popełnił samobójstwo, ci, którzy nie zginęli w czasie obławy, zostali aresztowani i otrzymali wieloletnie wyroki więzienia $^{5}$.

Historią tą oraz pierwowzorem literackim Stanisława Wałacha zainteresował się Aleksander Rowiński. W latach 70. XX wieku był on publicystą takich pism, jak „Życie Literackie” i „Kultura”. Scenariusz Krótkiego $\dot{z} y c i a$ był pierwszą rzeczą napisaną przez niego dla filmu. Jak wspomina, opowiadanie Wałacha zaproponował mu Tadeusz Konwicki, kierownik literacki zespołu filmowego „Pryzmat”:

Wręczył mi ten utwór Wałacha, powiedział, że to jest bardzo ciekawe dramaturgicznie i zapytał, czy nie przerobiłbym tego na scenariusz. Była to okazja, zwłaszcza, że

${ }^{3}$ Maciej Śliwa, Żandarmeria. Dzieje oddziału partyzantki antykomunistycznej w Beskidzie Sądeckim, „Almanach Muszyny” 2008, http://www.almanachmuszyny.pl/spisy/2008/ZANDARMERIA.pdf (dostęp: 9.04.2017).

${ }^{4}$ Tamże.

${ }^{5}$ Historia „Żandarmerii” i okoliczności jej likwidacji na podstawie: tamże. 
na zachętę Konwicki powiedział mi, że jest tym zainteresowany reżyser Kuźmiński, będący wtedy po dużym sukcesie filmu Agent $n r 1^{6}$.

Głównymi bohaterami scenariusza, noszącego tytuł Tymi samymi kartami, uczynił Wałach trzech mężczyzn. Pierwszy to Staszek Koczes, młody człowiek, który w czasie wojny walczył w Armii Polskiej na Zachodzie. Kolejnym jest „Emir", dowódca "Żandarmerii”, organizacji antykomunistycznej. Trzeci bohater to major UB, który namawia Koczesa do przeniknięcia do bandy „Emira”. Staszek jednak nie decyduje się na współpracę. Zmienia zdanie, gdy w miasteczku jest świadkiem napadu oddziału na halę targową. Koczesowi udaje się porozmawiać z jednym z jego członków i zabrać się z grupą w góry, gdzie mają swoją kryjówkę. Zanim jednak spotka się po latach z „Emirem”, przeżyje zaskoczenie, spotykając w górach „Szarotkę", swoją dawną sympatię, która jest w oddziale łączniczką.

Tymczasem „Emir" wysyła do Krakowa kilku żołnierzy, by dokonali „skoku” na konwój pieniędzy z jednego z banków. Zostają oni jednak złapani przez Urząd Bezpieczeństwa. Podczas przesłuchań jeden z nich - „Orlik” - zgadza się pokazać domniemaną kryjówkę, w której mają przebywać inni członkowie "Żandarmerii". „Orlik" wyrusza z milicjantami w góry. Był to jednak fortel, bo w pewnym momencie aresztowany mężczyzna popełnia samobójstwo, skacząc w przepaść.

Po długim oczekiwaniu Koczesowi udaje się jednak spotkać z „Emirem". Rowiński opisuje go w następujący sposób:

Był mężczyzną około trzydziestki, przystojnym i porywczym. Różnił się od swoich żołnierzy elegancją stroju. Miał dobry mundur z dystynkcjami porucznika. Leżał na nim świetnie. A wszystko razem - mundur, koalicyjka, kabura pistoletu z nowej skóry i wysokie buty, wyczyszczone jak do parady. Odcinały się dziwnym kontrastem od otaczającej rzeczywistości. Świadczyły, że za wszelką cenę - nawet za cenę śmieszności-Emir pragnie brylować7.

Podczas pierwszej po latach rozmowy Koczes próbuje wytłumaczyć „Emirowi”, że dalsza walka jest bezskuteczna - wojna dawno się skończyła, warto rozpocząć normalne życie i odnaleźć się w nowej rzeczywistości. Dowódca nie daje się jednak przekonać. Mało tego - powierza Staszkowi zadanie zorganizowania przerzutu oddziału na Zachód. Koczes przekazuje te

${ }^{6}$ Fragment Rozmowy autora artykułu ze scenarzysta Aleksandrem Rowińskim, maj 2017.

7 Tamże, s. 29. Filmowy kostium „Emira”, granego przez Eugeniusza Kamińskiego, w wielu punktach przypomina ten z opisu Rowińskiego. Jest jednak jedna różnica - „Emir" w Krótkim życiu ma na ramionach czerwoną naszywkę z białym napisem „Żandarmeria”. 
informację majorowi. Polska bezpieka konstruuje intrygę, która ma zwabić „Emira” i jego oddział w pułapkę. By to nastąpiło, zwracają się o pomoc do słowackich kolegów. Jeden z nich, znający język polski Karol, ma grać rolę „przewodnika”, który przeprowadzi oddział przez polsko-słowacką granicę. Koczes wyłuszcza swój plan „Emirowi”, zapoznaje go również z Karolem. Dowódca oddziału jest nieco nieufny, ale pokazane mu fałszywe dokumenty, które mają pomóc uciekinierom w pobycie na Słowacji oraz „legenda" Karola jako sprawdzonego przemytnika sprawiają że zgadza się na realizację tego planu. W tym samym czasie oficerowie służb bezpieczeństwa przygotowują górską gospodę, do której według pomysłu Karola i Koczesa mają trafić członkowie oddziału, by spędzić w niej noc. Zarówno goście gospody, jak i jej pracownicy, są tak naprawdę żołnierzami słowackiego UB. „Emir” zarządza jednak nocleg w lesie, bojąc się dekonspiracji i przypadkowych kontaktów ze Słowakami.

Rano Karol, Koczes, „Emir” i jego żołnierze schodzą do miasteczka. Wcześniej został w nim zainstalowany fałszywy przystanek autobusowy, a w odległym o kilka kilometrów garażu przygotowano podstawiony autobus, którego załoga - kierowca i konduktor - oraz pasażerowie, mający wsiadać do pojazdu na trasie, to funkcjonariusze słowackiego UB. Podczas drogi narasta atmosfera stresu i podenerwowania. $W$ trakcie podróży dochodzi do krótkiej przerwy spowodowanej zaimprowizowaną awarią autokaru, by inni "pasażerowie” zrezygnowali z dalszej jazdy. W autobusie zostają więc tylko „Emir" i jego ludzie. W tym momencie „Szaman”, wierny zastępca „Emira”, proponuje dowódcy, by porwać autobus i dojechać nim do samej granicy. Propozycja nie zostaje jednak przyjęta.

Tymczasem pojazd dojeżdża na miejsce zasadzki. Z głośników członkowie oddziału słyszą prośbę o poddanie się, czego „Emir" nie zamierza zrobić. Chce czekać do zapadnięcia zmroku, by pod osłoną nocy uciec z pułapki. Zaczyna również podejrzewać o zdradę swoich współpracowników. Ci jednak nie chcą walczyć dalej z "Emirem” i decydują się poddać. Wzburzony tym faktem „Emir” popełnia samobójstwo. Do członków oddziału zbliżają się żołnierze UB...

Porównanie scenariusza Aleksandra Rowińskiego z gotowym filmem Zbigniewa Kuźmińskiego przynosi konstatację o znaczących zmianach. Jednej z nich warto poświęcić trochę miejsca. Aleksander Rowiński zakładał bowiem w swoim scenariuszu zaangażowanie do filmu rzeczywistych uczestników tamtych wydarzeń. Na ekranie mieliby pojawić się więc zarówno polscy i słowaccy oficerowie, jak i dawni członkowie „Żandarmerii”. Sceny z ich udziałem stanowiłyby klamrę filmu. Na początku widzowie zobaczyliby więc Stanisława Wałacha, autora pierwowzoru literackiego, 
który wspomina lata 40. XX wieku i tamte działania. W kolejnej akcja filmu przeniosłaby się do Bratysławy, w której w swoim gabinecie słowacki oficer - Martin Benček, konsultant filmu ze strony słowackiej - wspomina likwidację oddziału „Emira”. Trzecia taka scena rozgrywała się już na planie filmu, gdzie pośród aktorów, reżysera i członków ekipy filmowej krążyli oficerowie, udzielając aktorom wskazówek i przywołując swoje wspomnienia z tamtych czasów. Według Rowińskiego rzeczywisty Stanisław Wałach miałby powiedzieć do grającego go aktora (w filmie rolę majora UB zagrał krakowski aktor Jerzy Aleksander Braszka): „Wzięliście na siebie wielką odpowiedzialność. Mieliśmy akurat tyle lat, co pan, co wy"8.

Ostatnia scena z udziałem rzeczywistych uczestników tamtej akcji została zaplanowana na koniec filmu. W niej, oprócz oficerów UB, mieliby również pojawić się dawni żołnierze "Żandarmerii". Ponadto Rowiński zakładał, że w tej scenie aktorzy, grający członków otoczonego oddziału mieliby możliwość porozmawiania z pierwowzorami swoich postaci i wydobycia od nich wspomnień na temat tamtych chwil. Taki zabieg nadałby filmowi dokumentalną otoczkę, a także, przynajmniej na polskim gruncie, zasłużyłby na miano prekursorskiego. Do 1976 roku zrealizowano sporo filmów o walkach z podziemiem antykomunistycznym, w żadnym z nich jednak na ekranie nie pojawiali się prawdziwi oficerowie UB czy dawni członkowie oddziałów, podobnych do "Żandarmerii", którzy w tamtych czasach trafili do więzień, gdzie odbyli surowe kary. Propozycje te nie zostały jednak przyjęte:

Pomysł wydawał mi się właściwy, natomiast Kuźmiński uważał, że to jednak nie
przejdzie. Podjął taką decyzję po konsultacjach na linii Konwicki-Wałach, wtedy od-
mówiono tego stanowczo. Trudno było przewidzieć, że zaproszeni ludzie na ten plan
wyrażą na to zgodę. Myślę, że był to główny powód rezygnacji. Natomiast pamiętam,
że na kolaudacji Jerzy Jesionowski, kiedy pod adresem filmu padały różne opinie,
bardzo silnie się upomniał, że scenariusz był daleko lepszy od tego, co zobaczyliśmy
na ekranie i wystąpił z pretensjami do Kuźmińskiego, że to pominął ${ }^{9}$.

Inną rzucającą się w oczy różnicą pomiędzy scenariuszem a scenopisem (autorstwa Aleksandra Rowińskiego i Zbigniewa Kuźmińskiego) i gotowym filmem jest usunięcie scen napadów dokonanych przez „Żandarmerię". W samym filmie występuje tylko jedna taka scena, która ma swoje miejsce po scenie rozmowy Koczesa z majorem UB. Tymczasem w scenariuszu Rowińskiego takich scen było więcej. Z filmu wypadły też wspomniane sceny z krakowskiej wyprawy rabunkowej członków

\footnotetext{
8 Tamże, s. 2.

9 Tamże.
} 
„Żandarmerii" na konwój bankowy. W filmie Kuźmiński pokazał tylko jej skutek - schwytanie przez Urząd Bezpieczeństwa „Orlika”, poszukiwanie kryjówki „Emira” i samobójczy skok.

Zasadniczą zmianą w stosunku do scenariusza jest również inne uzasadnienie rozmowy Koczesa z majorem UB. Rowiński nie zarysował konkretnych powodów tego spotkania. Miało ono miejsce już po pewnym okresie pobytu Koczesa w miasteczku. W scenopisie zaś Koczes, krótko po przyjeździe do miasta, wpada w kocioł zastawiony przez funkcjonariuszy UB. Założyli oni zasadzkę w mieszkaniu Kruczkowskiej, ciotki „Szarotki”, a więc dawnej sympatii Koczesa, którą on chciał odwiedzić.

Dalsza część scenariusza nie różni się diametralnie od filmu. Jedyną wartą dostrzeżenia różnicą jest śmierć „Emira”. Według Rowińskiego miał on, zaskoczony chęcią poddania się przez innych uciekinierów, ze słowami „Patrzcie, jak walczy żołnierz, wy ścierwa. Do końca!"10 popełnić samobójstwo. W gotowym filmie „Emir" zostaje zastrzelony przez pozostałych członków oddziału, a jego zastępca, „Szaman”, który przejął jego broń, zostaje rozbrojony.

\section{Okoliczności powstania filmu}

Po pozytywnym przejściu tekstu Aleksandra Rowińskiego przez sito komisji scenariuszowej film został 7 lipca 1975 roku skierowany do produkcji. W archiwach zachował się dokument pod nazwą Sprawozdanie ekonomiczno-organizacyjne z produkcji filmu "Krótkie życie”. Można się z niego dowiedzieć nie tylko, z jakimi trudnościami stykali się twórcy filmu, lecz także jak wyglądała praca we wszystkich fazach produkcji filmu. W swoich spostrzeżeniach, zebranych na potrzeby sprawozdania, kierownik produkcji Ryszard Barski z uznaniem wypowiadał się o kooperacji ze słowackimi filmowcami. W dokumencie stwierdził, że:

Film nasz był pierwszym realizowanym w koprodukcji z kinematografią słowacką. Pomimo całkowicie odmiennego systemu organizacji produkcji, z zadowoleniem należy podkreślić, że współpraca układała się dobrze. Kierownictwo kinematografii bardzo pozytywnie oceniło współpracę przy naszym filmie i nosi się z zamiarem kontynuowania jej w najbliższej przyszłości, co biorąc pod uwagę środki, jakimi dysponuje kinematografia słowacka, może przynieść naszej kinematografii wiele korzyści ${ }^{11}$.

10 Tamże, s. 139.

11 Sprawozdanie organizacyjno-ekonomiczne z filmu "Krótkie życie”, Archiwum Zespołu Polskich Producentów Filmowych, s. 14. 
Dodawał, że współpraca między wytwórniami oraz polskimi i słowackimi filmowcami układała się $\mathrm{w}$ duchu wzajemnego szacunku dla własnych metod pracy, wynikających ze wspomnianych "całkowicie odmiennych systemów organizacji produkcji”. Jak podsumowywał tę część sprawozdania Barski, „należy tutaj podkreślić, że słowackie Kierownictwo Produkcji w czasie zdjęć na terenie Polski całkowicie podporządkowało się naszemu systemowi organizacyjnemu"12.

W samych superlatywach o współpracy ze słowackimi kolegami wypowiadał się też reżyser filmu. W wypowiedzi dla „Filmowego Serwisu Prasowego", będącej swego rodzaju podsumowaniem pracy nad filmem, Zbigniew Kuźmiński stwierdził:

\begin{abstract}
„Debiutem” była także nasza współpraca z filmowcami słowackimi. Do podjęcia tej współprodukcji doszło w wyniku długotrwałych starań obu stron - chodziło przede wszystkim o taki temat, który współpracę tę mógłby zapoczątkować. [...] Gdybym jako kierownik grupy realizacyjnej miał wystawić noty za tę współpracę, za jej kształt produkcyjny, musiałbym posłużyć się oceną najwyższą; znaleźliśmy bowiem wśród słowackich kolegów wielu znakomitych profesjonalistów (operujących przy tym wspaniałym nowoczesnym sprzętem zdjęciowym), których udział w tym filmie trudno przecenić ${ }^{13}$.
\end{abstract}

W ekipie znalazło się sporo twórców, mających wieloletnią praktykę w kinematografii. Reżyser, Zbigniew Kuźmiński, pracę w filmie rozpoczynał pod koniec lat 40. XX wieku jako asystent Aleksandra Forda na planie Ulicy Granicznej, która była jednym z pierwszych polskich filmów nagrodzonych na międzynarodowym festiwalu filmowym. Następnie przez lata pracował jako drugi reżyser, współpracując między innymi z Antonim Bohdziewiczem, Leonardem Buczkowskim, Janem Rybkowskim czy Januszem Nasfeterem. W tej funkcji pracował również na planie Krzyżaków (1960) Aleksandra Forda. Jego debiut - Milczące ślady (1961) - poświęcony był podobnej tematyce, co Krótkie życie, opisywał bowiem walki z oddziałami NSZ na terenie Pienin. Wielką popularnością cieszył się Agent nr 1 (1971). Film z Karolem Strasburgerem w tytułowej roli był biografią Jerzego Szajnowicza-Iwanowa, Polaka z pochodzenia, agenta wywiadu brytyjskiego działającego na terenie Grecji, który przeprowadził tam wiele aktów dywersji i sabotażu, osłabiając tym armię hitlerowską. W latach 50. XX wieku, równolegle z funkcją asystenta reżysera, realizował spektakle w łódzkim ośrodku telewizyjnym. Warto dodać, że nie była

12 Tamże, s. 10.

${ }^{13}$ Krótkie życie, „Filmowy Serwis Prasowy” 1976, nr 9, s. 3. 
to pierwsza praca Kuźmińskiego poza polską granicą. Oprócz Agenta nr 1, który powstawał w Bułgarii i Grecji, Kuźmiński zrealizował też Zejście do piekła (1966), które zostało nakręcone na terenie Kuby. Krótkie życie wpisywało się więc w krąg zainteresowań reżysera, w którym znajdowała się głównie II wojna światowa i okres pierwszych lat po jej zakończeniu, przedstawione w przygodowej bądź sensacyjnej formie.

Wieloletnią praktykę $\mathrm{w}$ kinematografii $\mathrm{w}$ momencie pracy nad filmem miał również kierownik produkcji - Ryszard Barski, chociaż Krótkie $\dot{z}$ ycie było pierwszym obrazem, kręconym w koprodukcji z inną kinematografia, którego realizacją kierował. Wcześniej zdobywał doświadczenie na planie takich filmów, jak Krzyżacy (1960, reż. Aleksander Ford) i Jarzębina czerwona (1969, reż. Ewa i Czesław Petelscy) oraz serialu Kolumbowie (1970, reż. Janusz Morgenstern). Z reżyserem Zbigniewem Kuźmińskim pracował on w poprzedzającym realizację Krótkiego życia serialu Ile jest $\dot{z} y$ cia (1974). Z tego serialu do ekipy filmu trafili także inni doświadczeni pracownicy polskiego filmu - scenograf Adam T. Nowakowski [pracował m.in. na planie Ogniomistrza Kalenia (1961, reż. Ewa i Czesław Petelscy), Lalki (1968, reż. Wojciech Jerzy Has) czy Ocalenia (1972, reż. Edward Żebrowski)], operator kamery Zbigniew Hartwig [miał w swoim dorobku pracę na planie Rękopisu znalezionego w Saragossie (1964, reż. Wojciech Jerzy Has) i seriali telewizyjnych: Wojna domowa (1965, reż. Jerzy Gruza) i Chłopi (1972, reż. Jan Rybkowski)] oraz drugi reżyser Karol Chodura [początkowo operator, który pracę w polskiej kinematografii rozpoczynał na planie średniometrażowego filmu $2 \times 2=4$ (1945, reż. Antoni Bohdziewicz)].

W obsadzie aktorskiej znaleźli się zarówno już doświadczeni i zaprawieni w pracy przed kamerą aktorzy, jak i debiutanci oraz studenci szkół aktorskich. Główną rolę - Staszka Koczesa - zagrał Grzegorz Warchoł, który rok wcześniej kreował wiodącą postać w filmie Strach (1975, reż. Antoni Krauze). Eugeniusz Kamiński, odtwarzający rolę „Emira”, dowódcy "Żandarmerii", był już utytułowanym aktorem, mającym w swojej filmografii takie tytuły, jak Wolne miasto (1958, reż. Stanisław Różewicz) czy Jak rozpętałem II wojnę światowa (1969, reż. Tadeusz Chmielewski). Filmową „Żandarmerię" zagrali aktorzy z bogatą filmografią (Wirgiliusz Gryń czy Leopold R. Nowak), młodsi od nich, ale już często pojawiający się na ekranach Zbigniew Bielski, Andrzej Mrowiec, Andrzej Łągwa, Jerzy Rogalski i Lech Łotocki (ten ostatni ciekawie zarysowaną postać „Szamana”, zastępcy „Emira”, którą można uznać za najlepiej zagraną rolę w filmie), a także niedawni absolwenci czy studenci szkół aktorskich (Elżbieta Czaplińska w roli "Szarotki", dawnej sympatii głównego bohatera, Stanisław Biczysko, Stefan Paska, Włodzimierz Matuszak, Andrzej Szopa, Jan Szurmiej). 
Ze strony słowackiej do ekipy trafili zarówno szefowie poszczególnych pionów ekipy, jak i pracownicy pomocniczo-twórczy. Operatorem obrazu był Alojz Hanušek, który kilka lat po Krótkim życiu zrealizuje zdjęcia głośnego filmu Ja kocham, ty kochasz (1980, reż. Dušan Hanák), nagrodzonego Srebrnym Niedźwiedziem na Międzynarodowym Festiwalu Filmowym w Berlinie ${ }^{14}$. Na polskim gruncie współpracował on z reżyserem Kuźmińskim jeszcze przy innym filmie - produkcyjniaku Dźwig (1976), zrealizowanym dla Telewizji Polskiej. W Krótkim życiu zaprezentował on talent dobrego operatora, co zostanie później zauważone przez recenzentów. Ujęcia górskich krajobrazów, wśród których ukrywa się „Żandarmeria" czy interesująco zakomponowane sceny rozgrywające się podczas zasadzki na oddział bronią się do dzisiaj i stanowią bodaj największy atut filmu.

Ze strony słowackiej produkcją filmu kierował Aleksiej Artim, który legitymował się dłuższym nawet stażem w branży filmowej niż jego polski kolega. Pion scenografii i kostiumów także otrzymał słowackie wsparcie. Adama T. Nowakowskiego w jego pracy wspomagał Juraj Červík, a kostiumolożkę Hannę Kamecką - Júlia Ballagová. Ekipę słowacką stanowili również asystenci - reżysera (Eugen Bobek), scenografa (Viera Dekišová) i kierownika produkcji (František Dostál). W obsadzie znalazło się kilka słowackich i czeskich nazwisk, z których na wspomnienie zasługuje zwłaszcza Czech Vít Olmer w roli podstawionego przez Urząd Bezpieczeństwa przewodnika Karola. Stworzył ciekawą postać oddanego sprawie oficera, świetnie przygotowanego do swojej roli, zrównoważonego i rozsądnego, który nie poddaje się emocjom nawet wtedy, gdy misternie skonstruowanej przez oficerów bezpieczeństwa intrydze grozi fiasko. Stanowi on dobrą przeciwwagę dla postaci Koczesa, zaślepionego w miłości do "Szarotki” i robiącego wszystko, by uratować ją z zasadzki i ostrzec przed czyhającym niebezpieczeństwem. Poza Olmerem w filmie wystąpili również Petr Skarke i Jozef Husár w roli załogi podstawionego przez UB autobusu, Ján Rybárik jako komendant czechosłowackiego Urzędu Bezpieczeństwa, dowodzący akcją ze strony słowackiej oraz szereg aktorów w roli jego podwładnych. W Czechosłowacji Krótkie życie, w przeciwieństwie do polskiej wersji filmu, zostało zdubbingowane. Główny bohater, Staszek Koczes, przemówił tam głosem Milana Kňažko, późniejszego polityka i wieloletniego ministra kultury rządu słowackiego. W polskiej wersji kwestie słowackich aktorów zostały opatrzone napisami.

${ }^{14}$ Warto zauważyć, że główną rolę w tym filmie - Pisty - zagrał polski aktor Roman Kłosowski. 
Zdjęcia, kręcone od sierpnia do października 1975 roku, realizowano na terenie Polski i Słowacji. Sceny otoczenia „Żandarmerii” przez żołnierzy UB zostały nakręcone w okolicach Spiskiego Zamku. Według Ryszarda Barskiego cała ta sekwencja sprawiła realizatorom najwięcej problemów:

\begin{abstract}
Należy tutaj podkreślić, że akcja $60 \%$ filmu rozgrywała się w trakcie jednego dnia, co nakładało na realizatorów konieczność utrzymania charakteru zdjęć w tych samych warunkach pogodowo-świetlnych. Nakładało to na Kierownictwo Produkcji, tak polskie jak i słowackie, obowiązek sporządzenia dziennych planów pracy w trzech wariantach w zależności od pogody (słońce, pogoda pochmurna i deszcz) oraz bieżącego przygotowania trzech obiektów na zdjęcia w zależności od rodzaju $\operatorname{pogody}^{15}$.
\end{abstract}

Dodatkowym utrudnieniem było oddalenie bazy zdjęciowej w Popradzie o niemal $70 \mathrm{~km}$ od miejsca zdjęć, w przeciwieństwie do polskich obiektów, które zlokalizowane były (z jednym wyjątkiem) najwyżej $20 \mathrm{~km}$ od bazy. To powodowało również inne problemy, między innymi przekroczenie limitu nadgodzin przyznanego na ten film (przyznane przez Wytwórnię Filmów Fabularnych 1200 roboczogodzin zostało przekroczone o niemal połowę). Powodem tego było wspomniane oddalenie od miejsca zdjęć na Słowacji oraz trudności ze skoordynowaniem terminów pracy ze słowackimi aktorami, co, jak zauważał Barski, zmusiło twórców „do niezaplanowanej pracy w dwóch dniach świątecznych" ${ }^{16}$. Dodawał przy tym, że „na terenie Słowacji zmuszeni byliśmy dostosować się do wymagań słowackiego kontrahenta, u którego nie istnieje problem godzin nadliczbowych, a czas pracy limitują jedynie warunki świetlno-pogodowe $^{\prime 17}$. Niemniej jednak Ryszard Barski w swoim sprawozdaniu zauważał: „Skrócenie w tych warunków okresu zdjęciowego o 15 dni należy uznać jako sukces sprawnie działającej grupy zdjęciowej"18.

Problematyczne sytuacje zdarzyły się również na etapie postprodukcji i ich powodem była inna specyfika udźwiękawiania i kolaudowania filmu, przez co wystąpiły straty i opóźnienia. Jak notował Ryszard Barski: „Naszym zdaniem czas [...] zaplanowany wg. norm obowiązujących w Polsce był za krótki dla filmu realizowanego w koprodukcji"19. Kierownik produkcji wskazywał też niewywiązanie się strony słowackiej z obo-

\footnotetext{
15 Sprawozdanie organizacyjno-ekonomiczne z filmu "Krótkie życie”, s. 10.

16 Tamże, s. 12.

17 Tamże, s. 13.

18 Tamże, s. 10.

19 Tamże, s. 11.
} 
wiązków, wynikających z umowy, dotyczącej podziału pracy nad Krótkim $\dot{z}$ yciem. Odwołajmy się raz jeszcze do cytowanego Sprawozdania...

\begin{abstract}
Umowa ze Slovenską Filmową Tvorbą przewidywała wykonanie wszystkich prac związanych z napisami do filmu przez stronę słowacką. Napisy czołowe, które miały być wykonane w pierwszych dniach stycznia [1976 roku - przyp. J. G.], na skutek trudności technicznych $\mathrm{w}$ laboratorium w Bratysławie otrzymaliśmy dopiero 24 stycznia. Przedstawienie filmu do kolaudacji bez napisów stanowiących trwałą kompozycję plastyczną z obrazem pierwszego aktu było niemożliwe. Tak więc przegrany film przez 8 dni oczekiwał na kolaudację z powodów od nas niezależnych ${ }^{20}$.
\end{abstract}

Kolejne problemy wyniknęły również podczas końcowych prac nad filmem. $Z$ jednej strony słowacka wytwórnia filmowa pozytywnie rozpatrzyła prośbę polskiej strony o szybkie wykonanie kopii wzorcowej i wstrzymanie przy tym mniej pilnych prac nad innymi słowackimi filmami, z drugiej - opóźniła przesłanie pozostałych materiałów wyjściowych z powodów problemów technicznych i początkowego nieprzystosowania ich do polskich norm.

Koniec końców Krótkie życie, po pomyślnym przejściu kolaudacji (o czym wspomnę w kolejnej części), zostało z dniem 31 marca 1976 roku skierowane do rozpowszechniania. Polska premiera filmu miała miejsce 7 czerwca 1976 roku w Warszawie, zaś na Słowacji widzowie obejrzeli film po raz pierwszy niecałe trzy tygodnie później - 25 czerwca 1976 roku.

Ponad to trzeba nadmienić, że Krótkie życie nie było jedyną koprodukcją która w tym czasie powstała w Polsce. Janusz Majewski rok wcześniej, we współpracy z czeskimi filmowcami, zrealizował wybitne Zaklęte rewiry z genialnymi kreacjami Marka Kondrata i Romana Wilhelmiego. W 1976 roku powstały kolejne koprodukcje. Dagny Haakona Sandøya, zrealizowana z norweską wytwórnią Norsk Film, opowiadała rozgrywającą się we wnętrzach z epoki burzliwą historię miłości Dagny Juel i Stanisława Przybyszewskiego (w tej roli Daniel Olbrychski). Smuga cienia Andrzeja Wajdy, oparta na powieści Josepha Conrada, która powstała w koprodukcji z Wielką Brytanią, opisywała wątki biograficzne autora pierwowzoru literackiego. $W$ tym roku powstał również jeden z niewielu filmów zrealizowanych we współpracy polsko-japońskiej. Ognie sa jeszcze żywe, wyreżyserowane przez japońskiego twórcę Nobito Abe, były historią związku młodej Polki Krystyny (Bożena Dykiel) z Japończykiem Nobito, który umiera na chorobę popromienną. Na ich miłość nakładają się wspomnienia z polskiej i japońskiej historii - dramatu Powstania

20 Tamże. 
Warszawskiego i koszmaru Auschwitz oraz zrzucenia bomby atomowej na Hiroszimę i Nagasaki. Rok 1976 to również realizacja filmu Jana Łomnickiego Ocalić miasto, który opowiadał o ostatnich dniach okupacji niemieckiej w Krakowie i współdziałaniu żołnierzy AL i AK z oficerami Armii Czerwonej $\mathrm{w}$ wyzwoleniu tego miasta; powstał on przy udziale Wytwórni Filmowej „Mosfilm”.

\section{Odbiór filmu i głosy prasy}

Gotowe Krótkie życie, zanim trafiło na ekrany kin, musiało przejść kolaudację. Miała ona miejsce 27 stycznia 1976 roku; na szczęście w archiwum Filmoteki Narodowej zachował się stenogram z tego posiedzenia. Wzięli w nim udział przedstawiciele Zespołu Filmowego „Pryzmat” - Aleksander Ścibor-Rylski (kierownik artystyczny), Tadeusz Konwicki (kierownik literacki), Tadeusz Karwański (szef produkcji), reżyser Zbigniew Kuźmiński oraz przedstawiciele resortu kultury, literaci i dziennikarze. Można domniemywać, że film, podejmujący tematykę zgodną z ideologicznymi zaleceniami partii i ukazujący w dobrym świetle funkcjonariuszy UB, uzyska wysokie noty i spotka się z aprobatą. Chociaż uczestnicy posiedzenia nie mieli żadnych uwag, które wymagałyby zmian w filmie, to jednak w krytyczny sposób ocenili jego poziom. Właściwie tylko dziennikarz i krytyk filmowy Ryszard Koniczek, podówczas redaktor naczelny tygodnika „Kino”, w miarę łagodnie zrecenzował Krótkie życie. Zwrócił jednak uwagę na przewidywalność filmu i nużącą ekspozycję, stwierdził, że „film trzyma w napięciu i wszystko jest podporządkowane głównemu celowi dramaturgicznemu. Właściwie dwie trzecie filmu jest zrobione pełną parą i dla mnie są to rzeczy interesujące i ciekawe" ${ }^{21}$. W ogólnym zarysie odniósł się również do problematyki poruszonej przez Kuźmińskiego i Rowińskiego. Pochwalił twórców za rozsądne podejście do konfliktów, które miały miejsce $\mathrm{w}$ tamtych czasach, a o których wcześniej reżyser zrealizował już kilka filmów. W części swojej wypowiedzi, poświęconej kreacjom aktorskim, pochwalił on Jerzego Aleksandra Braszkę, grającego majora UB w sposób, zdaniem Koniczka, „przekonywający, ludzki”22. Krytycznie ocenił zaś postać „Emira”. Zdaniem dziennikarza:

${ }^{21}$ Stenogram z posiedzenia Komisji Kolaudacyjnej Filmów Fabularnych w dniu 27 stycznia 1976 r., Archiwum Filmoteki Narodowej, poz. A-344, poz. 107, s. 2.

${ }^{22}$ Tamże. 
ta sylwetka jest mało wiarygodna i bardziej bym mógł przyjąć tę postać, gdyby on był z większym polotem, a tak razi mnie naiwność tego człowieka w stosunku do zamierzeń Koczesa, on nie reaguje zupełnie na logiczne podszepty swego zastępcy i dlatego rysunek tej postaci jest dla mnie nie przekonywujący, bo jest on nierozgarnięty, a całe jego działanie nie jest uwierzytelnione od strony psychologicznej ${ }^{23}$.

W podobny sposób o filmie wyrażał się Zbigniew Safjan. Współautor scenariusza Stawki większej niż życie stwierdził, że „film ma walory, jest w nim sporo autentyzmu, jest sporo napięcia, szczególnie w części końcowej i chyba druga część jest zrobiona dość sprawnie. Wydaje mi się, że ten film można oglądać z zainteresowaniem [...]"24. Swoje wystąpienie poświęcił jednak również porównaniu Krótkiego życia z innymi filmami na ten temat. Zauważył, że chociaż film Kuźmińskiego ma pewne zalety i „będzie się go oglądało ze względu na wartości przygodowe, na niezłą, sprawną robotę reżyserską i na walory suspensowe" 25 , to nie wnosi nic nowego do dyskusji na temat tych czasów oraz konfliktów, jakie miały miejsce w Polsce w drugiej połowie lat 40. XX wieku. Według Safjana w Krótkim życiu występują:

elementy nam już znane, nie jest dla mnie przekonywująca panorama komplikacji, jakie występowały w tamtych czasach i trudno tutaj mówić o nowych elementach w sensie jakiegoś rozliczenia się, jakiegoś rozrachunku z okresem lat 1946-1947. Tutaj nic nowego niestety nie uzyskaliśmy ${ }^{26}$.

Podobnym tropem poszedł Jerzy Jesionowski. Odniósł on Krótkie życie do filmów Kazimierza Kutza i Henryka Kluby, a także do Ogniomistrza Kalenia Ewy i Czesława Petelskich, popularnego filmu z początku lat 60. XX wieku, który w sensacyjno-przygodowej formie odsłania historię żołnierza KBW, pełniącego swoją służbę w Bieszczadach tuż po II wojnie światowej oraz Wilczych ech Aleksandra Ścibor-Rylskiego, ukazujących ówczesne konflikty w poetyce westernu. Zwrócił uwagę, że od wydarzeń, o których opowiadają wspomniane filmy, minęło już ponad 30 lat, a co za tym idzie - „ta tematyka nie budzi emocji politycznych, a historia jednoznacznie rozstrzygnęła kto ma rację i widzowie nie mają obecnie żadnych wątpliwości”27. Wypowiadając się dość ogólnie na temat filmu Kuźmiń-

\footnotetext{
23 Tamże, s. 3.

24 Tamże.

25 Tamże, s. 4.

26 Tamże.

27 Tamże, s. 5.
} 
skiego i nie zgłaszając uwag, które wymagałyby zmian bądź przeróbek, Jesionowski stwierdził, że ostatnie próby polskich reżyserów w opowiadaniu o tamtych czasach nie przyniosły dobrych rezultatów. Zalecał inne podejście do tej problematyki, zwracając jednak uwagę na dość duże oczekiwania publiczności w odniesieniu na przykład do filmów sensacyjnych. „Jak tu można mówić o sensacyjności, jeżeli widz jest zorientowany, że bezpieczeństwo wie o tej grupie, która jest przemycana na Zachód, jeżeli widz jest przekonany, że partyzanci wpadną w ręce bezpieczeństwa"28 - pytał Jesionowski i zachęcał do dyskusji na ten temat.

Filmu próbowali bronić Zbigniew Kuźmiński oraz Aleksander Ścibor-Rylski. Pierwszy z nich porównywał swój film do westernu i przekonywał, że znajomość reguł gatunku i obrazów zrealizowanych w takiej konwencji nie sprawia, że widzowie nie angażują się emocjonalnie w ich odbiór. Odniósł się również do zarzutów o brak nowych elementów w jego filmie. Zdaniem reżysera sam fakt podjęcia historii, która zdarzyła się w rzeczywistości, a ponadto była wspólnym działaniem służb bezpieczeństwa dwóch krajów, świadczy o pewnym novum $\mathrm{w}$ opisywaniu pierwszych powojennych lat. Zwrócił również uwagę na samo poprowadzenie tej historii i zbudowanie postaci stojących po różnych stronach barykady. Według Kuźmińskiego:

mamy do czynienia z ludźmi stojącymi na straconych pozycjach politycznych, którzy w dodatku nie otrzymują wiadomości ze swojego ośrodka dyspozycyjnego. Mimo ich ciężkiej sytuacji nie mamy odczucia, że zostaną oni wyrzuceni poza nawias społeczeństwa, to nie są ludzie, których należałoby spisać na straty, czy też brutalnie rozstrzelać ${ }^{29}$.

W podobny sposób, jako element różnicujący Krótkie życie od innych produkcji o tej tematyce, traktował postaci oficerów Urzędu Bezpieczeństwa. Dowodził, że każdemu z nich zależy na tym, aby w akcji tej nikt nie zginął, co ma świadczyć o ich humanitaryzmie. Przekonywał też, że członkowie oddziału nie są ukazani jako „czarne charaktery” (w tym przypadku można polemizować, niemniej trzeba przyznać, że zwłaszcza najmłodsi członkowie "Żandarmerii" są zaprezentowani przez reżysera i scenarzystę jako sympatyczni i w kilku momentach wykazujący się szlachetnością i przyzwoitością ${ }^{30}$ ). Kuźmiński zakończył swą polemikę zda-

28 Tamże, s. 6.

29 Tamże, s. 7-8.

30 W tym miejscu warto przywołać fragment scenariusza, który nie został ostatecznie zrealizowany. Scena 33 opisywała spotkanie członków "Żandarmerii” z miejscowym chłopem. Był on przekonany, że ma on do czynienia z żołnierzami KBW. Chciał im wskazać drogę do kryjówki „Emira”, za co jego żołnierze wykonywali na nim wyrok śmierci. 
niem niemalże zaczerpniętym z ostatnich stron scenariusza Rowińskiego: „,jako realizatorzy nie możemy powiedzieć, że my tych ludzi z oddziału nie lubimy, a już na pewno nie przekreślamy, chcemy im pomóc, chcemy im podać rękę, nie chcemy, żeby oni dalej stali na tych straconych pozycjach"31. Również Aleksander Ścibor-Rylski zgodził się z Kuźmińskim i potwierdził, że jego zdaniem ,jest to temat poważny i poważnie zostali potraktowani przedstawiciele obu stron" ${ }^{\prime 2}$. Przyjmując wszelkie zarzuty, jakie zostały postawione samemu filmowi, jak i jego twórcom, proponował jednak nie mieć nazbyt wygórowanych oczekiwań przed kolaudacją każdego filmu produkcji polskiej. Określił również Krótkie życie jako próbę „nieco spokojniejszego mówienia o tych bolesnych sprawach" ${ }^{33}$.

Niechętnie do Krótkiego życia podeszli też recenzenci. Cezary Wiśniewski, recenzent „Sztandaru Młodych”, uznał film za połowiczne osiągnięcie, wytykając banał i powielanie ogranych już schematów, co uwidacznia się zwłaszcza w pierwszej części filmu. Chociaż pochwalił zdynamizowanie akcji w dalszych partiach i zwrócił uwagę na dobre zdjęcia Alojza Hanuška, uznał jednak Krótkie życie za jeden „,z najsłabszych aktorsko filmów sezonu" ${ }^{\prime 34}$, z którego w pamięci zostają tylko nieliczne postacie. Stanisław Grzelecki z "Życia Warszawy” zwrócił uwagę na wykorzystanie przez twórców motywu znanego z Konrada Wallenroda Adama Mickiewicza. Wytknął jednak Zbigniewowi Kuźmińskiemu nieumiejętne wykorzystanie zalet scenariusza. „W scenariuszu Aleksandra Rowińskiego jest wiele epizodów, które ożywiłyby każdy western i każdy film gangsterski. W reżyserii epizody te nieco bledna, wydaje się, że zawarta w nich treść dramatyczna oraz napięcie sytuacyjne nie zostały wydobyte $\mathrm{w}$ całej pełni"35 - puentował swoją recenzję. Znacznie łaskawiej potraktował Krótkie życie recenzent „Filmu”, Bogdan Zagroba. Docenił sprawną realizację sensacyjnego filmu, umiejętne dawkowanie napięcia (szczególnie w końcowej sekwencji pułapki, zastawionej $\mathrm{w}$ autobusie, zakończonej buntem przeciwko „Emirowi"). Według krytyka film był jednak obarczony pewnymi wadami - dramaturgicznymi i realizacyjnymi. Bardziej negatywnie Krótkie życie zostało odebrane przez recenzenta "Ekranu”, Henryka Tronowicza. „Lecz zaprzepaścić sposobność wykazania narratorskiej sprawności, dysponując intrygą z mknącym przez Słowację autobusem, to już wywołuje zniecierpliwienie! A przecież aż się prosiło, żeby na tej intrydze całą tę

31 Stenogram z posiedzenia Komisji Kolaudacyjnej Filmów Fabularnych..., s. 8.

32 Tamże, s. 10.

33 Tamże.

${ }^{34}$ Cezary Wiśniewski, Krótkie życie "Emira”, "Sztandar Młodych” 1976, nr 137.

35 Stanisław Grzelecki, Praktyki i zasady, ",Życie Warszawy” 1976, nr 42. 
historię skonstruować" ${ }^{36}$ - pisał. Narzekał na brak zindywidualizowania postaci członków "Żandarmerii”, przesadną ekspresję zniecierpliwienia i przerażenia sytuacją rozgrywającą się $\mathrm{w}$ autobusie oraz przewidywalność intrygi. W podobnym tonie wypowiadał się Jerzy Niecikowski w recenzji o wiele mówiącym tytule $O$ bandach raz jeszcze. "Wszystkie te sceny [ekspozycji - przyp. J. G.] szyte są grubymi nićmi, a prawdę powiedziawszy nie ma tu nic prócz nici" ${ }^{37}$ - pisał i wytykał również filmowi "sztuczność” oraz „nieudolność psychologiczną i dramaturgiczną" ${ }^{38}$. Wszelkie pozostałe recenzje nie różniły się zbytnio od wcześniej zacytowanych, a także od krytycznych opinii wygłoszonych przez członków komisji kolaudacyjnej. Nawet obszerna recenzja, która znalazła się w jednym z numerów czasopisma "Za Wolność i Lud”, zawiera niemal same uwagi pod adresem reżysera i negatywnie podsumowuje zarówno scenariusz, jak i film; autorka zwraca uwagę, że biorąc pod uwagę wcześniejsze dokonania reżysera oraz realizację filmu na podstawie pamiętników Stanisława Wałacha, można było oczekiwać lepszych rezultatów ${ }^{39}$.

Tytuły recenzji, które ukazały się na Słowacji - Taký život je naozaj krátky (Takie życie jest doprawdy krótkie), Príliš skromná ponuka (Oferta zbyt skromna), Problémy s koproduciou a výběr témy (Problemy z koprodukcją i wyborem tematu $)^{40}$ - wskazują na równie chłodne przyjęcie filmu. Słowaccy historycy filmu sytuują dziś Krótkie życie w szeregu filmów będących znakiem ewoluującego podejścia do tematu II wojny światowej: odstęp czasowy od wydarzeń z jednej strony skutkował poszukiwaniem nowych sposobów obrazowania okrucieństw tego czasu, z drugiej zaś - i w tym kontekście wspominany jest film Kuźmińskiego - pozwolił na portretowanie wydarzeń wojennych w konwencji filmu przygodowego ${ }^{41}$.

Jak wspomniałem na samym początku, Krótkie życie jest dziś filmem zapomnianym i nieznanym. Powodem tego jest zapewne podjęty temat, który już w tamtym czasie nie budził zainteresowania publiczności, a w dzisiejszych czasach, także ze względu na sposób opowiadania i przyjęty punkt widzenia, byłby dla publiczności mało atrakcyjny. Na brak popularności filmu nie wpłynął również jego poziom artystyczny, który znacznie odbiega od innych filmów polskich z tamtych lat. Pamiętać trzeba, że mniej więcej

\footnotetext{
${ }^{36}$ Henryk Tronowicz, Zasadzka bilateralna, "Ekran” 1976, nr 25, s. 20.

37 Jerzy Niecikowski, O banatach raz jeszcze, „Film” 1976, nr 26, s. 5.

38 Tamże.

39 A.Z., Krótkie życie, „Za Wolność i Lud” 1976, nr 31.

40 Renáta Šmatláková, Katalóg slovenských celovečerných filmov..., s. 106.

${ }^{41}$ Václav Macek, Jelena Paštéková, Dejiny slovenskej kinematografie, Vydavatel'stvo Osveta, Martin 1997, s. 335-336.
} 
w momencie wejścia Krótkiego życia na ekrany, premiery miały tak wybitne i wskazujące wady ówczesnego systemu obrazy, jak Człowiek z marmuru (1976, reż. Andrzej Wajda), Barwy ochronne (1976, reż. Krzysztof Zanussi) czy komedia Stanisława Barei Brunet wieczorowa pora (1976). W telewizyjnych serialach zaś zjednywali sobie sympatię widzów inżynier Karwowski z serialu Czterdziestolatek (1974-1977, reż. Jerzy Gruza) i porucznik Borewicz z 07 zgłoś się (1976-1987, reż. Krzysztof Szmagier, Andrzej Jerzy Piotrowski i Kazimierz Tarnas). Chociaż pierwsza na gruncie kinematografii współpraca Polski i Słowacji z punktu widzenia organizacyjnego powiodła się dobrze, to jednak jej końcowy efekt, czyli film Zbigniewa Kuźmińskiego, szybko popadł w zapomnienie i obecnie można go zobaczyć tylko w archiwach.

\section{Bibliografia}

\section{Archiwalia}

Rowiński Aleksander, Scenariusz filmu Tymi samymi kartami. II wersja, Warszawa 1975, Archiwum Filmoteki Narodowej, poz. A-344, poz. 107.

Rozmowa autora ze scenarzysta Aleksandrem Rowińskim, maj 2017.

Sprawozdanie organizacyjno-ekonomiczne z filmu "Krótkie życie”, Archiwum Zespołu Polskich Producentów Filmowych.

Stenogram z posiedzenia Komisji Kolaudacyjnej Filmów Fabularnych w dniu 27 stycznia 1976 r., Archiwum Filmoteki Narodowej, poz. A-344, poz. 107.

\section{Druki zwarte}

Macek Václav, Paštéková Jelena, Dejiny slovenskej kinematografie, Vydavatel’stvo Osveta, Martin 1997.

Šmatláková Renáta, Katalóg slovenských celovečerných filmov 1921-1999, Slovenský filmový ústav, Bratislava 1999.

\section{Czasopisma}

Grzelecki Stanisław, Praktyki i zasady, „Życie Warszawy” 1976, nr 42.

Krótkie życie, "Filmowy Serwis Prasowy” 1976, nr 9.

Niecikowski Jerzy, O banałach raz jeszcze, „Film” 1976, nr 26.

Śliwa Maciej, Żandarmeria. Dzieje oddziału partyzantki antykomunistycznej w Beskidzie Sąeckim, „Almanach Muszyny” 2008, nr 1, http://www.almanachmuszyny.pl/spisy/2008/ ZANDARMERIA.pdf (dostęp: 9.04.2017).

Tronowicz Henryk, Zasadzka bilateralna, „Ekran” 1976, nr 25.

Wiśniewski Cezary, Krótkie życie „Emira”, „Sztandar Młodych” 1976, nr 137.

A.Z., Krótkie życie, „Za Wolność i Lud” 1976, nr 31. 


\section{Streszczenie}

Krótkie życie (Krátky život, 1976) Zbigniewa Kuźmińskiego jest dzisiaj filmem zapomnianym i od lat nieemitowanym. Abstrahując od politycznych i ideologicznych aspektów tego obrazu, warto wspomnieć o nim przynajmniej z jednej przyczyny. Była to pierwsza polska produkcja zrealizowana we współpracy z Wytwórnią Filmową Koliba z siedzibą w Bratysławie. Celem artykułu jest przybliżenie zarówno autentycznych wydarzeń, będących podstawą scenariusza, jak i przebiegu produkcji (szczególny nacisk kładąc na kooperację dwóch kinematografii) oraz przyjęcia filmu przez oficjalne organy i recenzentów prasowych. Przywołane zostały m.in. protokoły z kolaudacji filmu, fragmenty scenariusza, a także sprawozdanie autorstwa kierownika produkcji Krótkiego życia. 